\title{
Use of intelligent applications to reduce household food waste
}

\author{
by Liegeard, J. and Manning, L.
}

Copyright, Publisher and Additional Information: This is the author accepted manuscript. The final published version (version of record) is available online via Taylor \& Francis

Please refer to any applicable terms of use of the publisher.

DOI: https://doi.org/10.1080/10408398.2018.1556580 
Use of intelligent applications to reduce consumer food waste Julie Liegeard ${ }^{1}$ and Louise Manning ${ }^{2 *}$

\author{
${ }^{1}$ Ecole Supérieure d'Ingénieurs Réunion Océan Indien
}

${ }^{2}$ Harper Adams University, Newport, Shropshire, UK TF108NB

*corresponding author

\title{
Abstract
}

Household food waste is gaining an increasing emphasis worldwide. Multiple factors have been identified that contribute to household food waste including a lack of consumer understanding of durability coding and expiration dates on food. The aim of research is to review the evolution of date labelling and associated on-pack information, its interrelationship with household food waste, and potential future developments in intelligent applications to address food waste, transparency of communication and food safety. The length of shelf-life influences food waste with a longer shelf-life leading to less waste. Whilst preservatives extend shelf-life, the trend towards "clean labels" means that alternative intelligent approaches may be required that meet the expectations of consumers, improve personal agency in terms of improving product storage conditions, purchasing behaviour to minimise food waste and support effective household inventory management. Intelligent options considered in this paper include: intelligent packaging and also intelligent appliances as part of an internet of things (IoT) enabled "smart kitchen".

\section{Keywords IoT, internet of things, smart kitchen, smart fridge}

\section{Introduction}

As a result of profligate human activity, and due to its various social, economic and environmental impacts (European Parliament, 2017), food waste is taking on increasing importance worldwide. In 2011, global food waste represented one third of total food and beverage production, equivalent to 1.3 billion tonnes per year (FAO, 2011). In Europe, the percentage of waste reaches $20 \%$ of total production or 88 million tonnes (Stenmarck et al. 
2016), and in the United Kingdom (UK), annual food and beverage waste was 16 million tonnes (Quested and Parry, 2011). In 2017, the European Parliament set a target of halving food waste by 2030 (European Parliament, 2017) a difficult goal to achieve.

Whilst total volumes of food waste are of interest, quantifying food waste per capita gives a more meaningful metric that consumers can both understand and engage with. For example, at retailer and consumer level, food waste for the United States of America (USA) is $188 \mathrm{~kg}$ per capita/year, in the UK $181 \mathrm{~kg}$ per capita/year (Garrone et al. 2014), and in European Union (EU) countries slightly less at 179kg per capita/year (Buzby and Hyman, 2012, O'Connor et al. 2014). By reducing or preventing per capita food waste, it will be possible to mitigate the associated negative impacts. First, food waste raises social and political questions (Henderson, 2004, Stuart, 2009). Despite the abundance of food products and associated waste, $5.7 \%$ of Americans (Coleman-Jensen et al. 2014) and 9.6\% of Europeans (European Parliament, 2017) suffer from social disorders associated with food consumption such as malnutrition or difficulties within their immediate food environment e.g. sufficient access to food or poor cooking behaviour. Secondly, waste has a negative impact on the environment. Indeed, the environmental impact involves all stages of the product's life cycle, from production to destruction. As such, wasted products are responsible for an overall carbon footprint of approximately $8 \%$ of global anthropogenic greenhouse gas emissions (GHGs) see European Parliament (2017) and 28\% of usable resources (Spada et al. 2018) in Europe. GHGs occur during production and also during destruction of food via methane accumulation in landfills (Hogg et al. 2007; Stuart, 2009; Griffin et al. 2009; Mena et al. 2011). In the UK, greenhouse gas emissions from food waste disposal are equivalent to $30 \%$ of total consumption-related emissions (Mena et al. 2014). There is a resultant loss of utilised natural resources, such as water, energy and land, for food products that end up in the landfill (Lundqvist et al. 2008; Nellman et al. 2009; Stuart, 2009; Mena et al. 2011). Indeed, the loss of 30\% of the food 
produced implies the use of an additional $50 \%$ of water resources for irrigation (European Parliament 2017). Finally, the economic impact comes from the loss related to the production and purchase of a product that will not fulfil its primary function and will therefore be discarded (Mena et al. 2011). Indeed, food waste at European level is estimated at 143 billion euros per annum. Thus reducing waste will reduce economic losses at multiple steps in the food supply chain (Ventour, 2008; Mena et al. 2011). So, more specifically, what are the causes of household food waste?

\section{Factors affecting Household Food Waste}

In Europe, consumer level food waste is estimated to represent more than $50 \%$ of overall food waste post farm (Stancu et al. 2016, European Parliament, 2017). Including the losses within agriculture, in Europe and North America, 20\% of food waste occurs in the food supply chain and $10-15 \%$ of waste is by the consumer (Osborn, 2016). In the UK, WRAP (2009) estimated that half of overall food waste (around 8 million tonnes) is produced by consumers with a more recent study suggesting consumer food waste can be differentiated as 1.6 million tonnes of unavoidable waste and the rest as avoidable or possibly avoidable (such as peeling) waste (Osborn, 2016). Avoidable waste means that the product was still edible when being discarded. Avoidable and partly avoidable food waste is estimated to cost $£ 480$ per year for UK households or about $15 \%$ of their total expenditure on food and drinks (WRAP, 2009). By comparison, in the US, avoidable food waste is estimated to be up to $\$ 936$ per household per year (Buzby and Hyman, 2012; Blondin et al. 2015). Studies have shown that consumers are unaware of the amount of food waste they produce (Schanes et al. 2018). Furthermore, due to potential bias, studies that are based on self-reported behaviours cannot necessarily provide usable results to assess household food waste as respondents may be motivated to misreport (Møller et al. 2014; Neff et al. 2015). 
Whilst consumers consider throwing away food as inappropriate behaviour (Schanes et al. 2018), there is a gap between intention and actual behaviour to reduce waste food at the household level. Household food waste comes from both the interaction of multiple behaviours and the context in which the consumer is handling food, where handling food includes shopping, storing, preparing and cooking food as synthesized in Figure 1.

\section{Take in Figure 1}

Many studies have highlighted the fact that date labelling is considered as a key factor in food waste within the food supply chain, especially at the consumer/household level (Rahelu, 2009; Van Boxstael et al. 2014; Osborne, 2016; Hall-Phillips and Shah, 2017; Gaiani et al. 2018; Spada et al. 2018). Rahelu (2009) explained that in the UK 410 thousand tonnes of food, that is still safe to eat but has passed the 'best before' date, is thrown away each year and a further 220 thousand tonnes of food is thrown away whilst still within the 'best before' date". Other research suggests that wastage linked to food exceeding the stated date code, at the UK consumer level reaches $30 \%$ of total food purchases (Ceuppens et al. 2016). By comparison, in Sweden this percentage falls to $9 \%$. Studies have shown that the main issue for consumers with regard to date labelling is the lack of knowledge about how to use the information (Rotfeld, 2009; Hall-Phillips and Shah, 2017). It is suggested that $15-35 \%$ of the household waste in Europe is due to the lack of clarity of product information, such as the date label. (SANTE/2016/E1/024). The length of shelf-life too influences food waste behaviour at consumer level (Spada et al. 2018). In the context set out here, the aim of paper is to review the evolution of date labelling and associated on-pack information, its interrelationship with household and consumer food waste, and potential future developments in intelligent applications to address food waste, transparency of communication and food safety. The paper is structured as follows: firstly there is an introduction, followed by a contextualisation of the challenge of consumer food waste. The evolution of date coding legislation is outlined and then 
how food product shelf-life is determined and influenced by a range of processing techniques and product formulation. The use of intelligent applications both to extend shelf-life and as part of a smart kitchen approach via the "smart fridge" is explored.

\section{Product duration date coding - a timeline}

Since the 1960s, Europe has applied a model of continuous development in consumer law. In 1978, Europe implemented Directive 79/112/EC on the harmonisation of Member States' laws relating to the labelling, presentation and advertising of foodstuffs for sale to the ultimate consumer. This directive defines all the information that must appear on products and also led to the implementation of two labels: "use by" date and "date of minimum durability" or the "best before" date. This Directive was subsequently amended in 1989 and again in 1991 by Directive 89/395/EEC with regard to the indication of the date and the batch number on the labelling of pre-packaged products. It is now mandatory to apply a use-by date for all microbiologically highly perishable foods.

In order to protect consumer health and safety, other directives have been implemented, in particular Directive 2001/95/EC on general product safety and Regulation 178/2002 laying down the general principles and requirements of food law, establishing the European Food Safety Authority and laying down procedures in matters of food safety known as the "hygiene regulation". Regulation (EC) No 2073/2005 supports and provides information on microbiological criteria for foodstuffs. The criteria may be used in particular for the determination of the "use by date" or "minimum durability date" by microbiological monitoring. For this legislation to be effective in protecting consumer health and wellbeing there needs to be a clear understanding of the terms and their meaning.

More recently, the EU Regulation 1169/2011 on the provision of food information to consumers addressed date coding redefined terms such as: "Minimum durability date" (MDDs) 
is defined as "the date until which the food retains its specific properties under appropriate storage conditions" and should be replaced by the "use-by date" in the case of "foods which are microbiologically highly perishable and which are therefore likely, after a short period, to present an immediate health hazard". This regulation also proposed a list of foods that may be exempt from MDDs.

Milne (2012) describes the evolution of date coding in the UK and the impact of consumer requirements on labelling and the recurrent problem of the level of knowledge about shelf-life and household behaviour. The UK history of date labelling can be determined in four periods: stock management in late XIX ${ }^{\text {th }}$ and early $\mathrm{XX}^{\text {th }}$ century, consumer protection in the 1960 s, food safety in the mid-1980s and waste management in 1989 (Milne, 2012). The interest in formalising the "sell by" date gained importance in Europe, but by 1970 the UK had no mandatory form for such date coding. In the early 1970s, the UK Food Standards Committee was asked to revisit the date coding system to improve the consumer's "right to know". With the support of the government with the creation of the "Steering Group on Food Freshness" (SGFF), the launch of the first form of mandatory coding was based on the product quality. Indeed, common sense was that existing legislation protected consumers enough regarding food safety. At the beginning, dates used on packaging were date stamps, dates of production or "eat by" date. The problem was that the consumer interpreted those terms and the labelling was not clear enough about product freshness. In 1973 with the recommendations of the UK Food Standards Committee, a "sell by" date label was adopted, unlike Europe that had favoured dates aimed at the consumer rather than at businesses. Yet, it was only in 1980 that the Food Labelling Acts were harmonised in the UK with European Regulation 79/112/EC. The UK had obtained a derogation for the use of the 'sell by' date system, instead of the 'best before' date commonly accepted in Europe. Due to the Chernobyl cloud in the mid-1980s, the British food system was subject to an associated food scare. Indeed, many reports denounced invisible chemical hazards 
and food-borne pathogens. In the next few years, others food crisis occurred such as the bovine spongiform encephalopathy (BSE) crisis and together empowered collective consumer anxiety. In 1989, after an outbreak of Salmonella, the Institute of Environmental Health Officers asked for a more safety focused date label such as the "eat by" date. In 1980, the EU directive removed the UK's derogation for using the "sell by" date and introduced "use by" date coding. This new date labelling system was focused on food safety and introduced new requirements for consumer knowledge and focused on consumer health rather than stock control.

In the late 2000s, the worries about food waste at the retailer and household level had gained ground. One of the issues associated with household food waste is the confusion and lack of differentiation by consumers over date labels i.e. that "use by" date is about "safety" and "best before" about "quality" with an estimated quarter of food waste being due to food meeting or being over the expiry date (Ventour, 2008). However, it is important to consider that such consumer behaviour and loss of agency can arise from either a lack of knowledge and understanding or a lack of company transparency in the use of duration dates. It is hard for consumers to use best practices when they are confused especially when within the same product group, the date label can switch in type across the category from "use by" to "best before" or vice versa. (Milne 2012). Although the Department for Environment, Food and Rural Affairs (DEFRA, 2011) guide proposes a "decision tree" for labelling (Figure 2), application is more complicated for companies due to their degree of access to microbiology experts, equipment or situational food safety and integrity risk (Newsome et al. 2014.)

\section{Take in Figure 2}

The practices and procedures to be followed for determining duration dates lie within the responsibility of the manufacturer not only to choose the appropriate label but also to carry out the studies necessary to estimate the shelf-life of the product. The decision tree (Figure 2) 
lays the groundwork for a general guide to determine the key factors leading to the application of label dates. In order to define the appropriate date label, manufacturers have to consider the relevant legislation (Regulation (EC) No 2073/2005) that applies to microbiological risk and focuses on which reference organisms need to be considered. For example, the microorganism of reference for ready-to-eat food is Listeria monocytogenes (Ricci et al. 2018).

The "use by" date can be used for two different reasons. In the first instance, the limiting factor will relate mainly to the rate of growth of pathogenic microorganisms and spoilage organisms. The second case is limited by quality reasons as in some products growth of spoilage organisms could be quicker than pathogenic bacteria and the food could reach the sensorial spoilage limit before being a food safety risk and still bear a "use-by" date (van Boxstael et al. 2014). Thus the duration date or shelf-life needs to be determined for any given food and one element that acts as a mediating factor is the degree of and type of processing that the food has undergone.

\section{Determination of shelf-life}

Shelf-life is defined as the period during which a food product maintains its microbiological safety and suitability at a specified storage temperature and, where appropriate, in specified storage and handling conditions (Codex Alimentarius, 1999). Thus the shelf-life of an ingredient or food product is influenced by a number of factors often grouped together under the terms Good Manufacturing Practice (GMP) or Good Hygiene Practices (GHP). GMP encompasses the implementation of effective hazard analysis critical control point (HACCP) based food safety procedures, the precautions undertaken to ensure the quality of raw materials, effective management of processing steps, that appropriate packaging is used, there are adequate conditions of distribution, appropriate storage temperatures are maintained, that appropriate specifications are developed that include relevant product attributes and features that influence microbiological safety e.g. $\mathrm{pH}$, aw, salt and sugar concentration, use of 
preservatives, and consideration of the intended use and the target consumers (DEFRA, 2011). Many methods to extend food product shelf-life have evolved over time from drying and cooking in pre-history to the use of salt and sugar and then to refrigeration, pasteurisation, the use of chemical preservation and more recently the advent of smart and active packaging (Figure 3).

\section{Take in Figure 3}

However as a result of increasing health concerns associated with sugar and salt intake and consumption of energy dense foods (van Gunst et al. 2018), there is a strong drive to replace salt (Wyness et al. 2012) and sugars with other alternatives (van der Sman and Renzetti, 2018). Reducing these two preservatives can impact on shelf-life, flavour and functionality (Inguglia et al. 2017). The length of the product's shelf-life does have an influence on consumer food waste as consumers tend to waste less food when the shelf-life of the product is longer than 30 days (Spada et al. 2018). Thus shelf-life extension could be a means to reduce the level of consumer food waste and thus environmental impact. Examples include: the addition of rosmarinic acid as an antioxidant to extend the shelf-life of bakery products (Bacenetti et al. 2018), use of antifungal peptides, ethanol and plant extract in bread (Axel et al. 2017) and chitosan coating of fresh fruit and vegetables (Romanazzi et al. 2017). However at the same time there is a trend towards clean labels i.e. a reduction in food components that are seen as artificial, unhealthy or unfamiliar and increasing presence of claims such as "free from" (Asioli et al. 2017). Indeed in processed foods components such as energy, salt, sugar and saturated fats and additives (E-numbers) are seen as "negative nutrients" prompting reformulation and a drive for clean labels (van Gunst et al. 2018). Clean labels therefore are those with minimal ingredient lists and a drive for "clean labels" leads to a market and consumer resistance to products containing multiple additives (Buttriss, 2013). This consumer concern also extends towards what is perceived as either replacement ingredients or "unnatural technologies" to 
replace sodium in food (Regan et al. 2017). Preservation methods themselves can have an "harm-related" impact on the consumer, (Table 1) either directly (e.g. toxicity, blood pressure, dental problems or obesity) or indirectly e.g. decreasing the nutritional value of the food.

\section{Take in Table 1}

This means that different methods should be researched that can extend shelf-life. An alternative to either food processing steps to extend shelf-life and/or the addition of preservatives or chemicals is firstly the use of interactive packaging to communicate more effectively about the shelf-life of the product to the consumer. The Internet of Things (IoT) is a means of communication whereby objects (home appliances, cameras, monitoring sensors, actuators, displays, equipment) of everyday life contain technology that allow them to digitally connect and communicate with one another and with their users for the user's benefit (Deokar et al. 2018). Thus intelligent approaches via the use of packaging could utilise IoT concepts to support consumers to reduce household food waste.

\section{Interactive packaging}

Packaging is said to be interactive when it 'performs some role in the preservation of the food other than providing an inert barrier to outside influences' (Rooney, 1992; Rooney, 2012). There are multiple examples of interactive packaging including antimicrobial and antioxidant films, temperature control indicators, ethylene absorbing materials, oxygen/carbon dioxide absorbents such as iron and ascorbic acid and carbon dioxide generators, ethanol vapour generators and processes such as modified atmosphere packaging (Rooney, 2012) Interactive packaging aims to "extend product shelf-life and to communicate information which has historically been done through the use of product duration codes such as "use by" or "best before"' (Manning, 2018). Thus, this packaging can have an active role in preventing food waste by preserving product quality and safety and ensuring a lower overall ecological impact 
(Gutierrez et al. 2017). Numerous studies have been conducted to explore the different types of interactive, intelligent and active packaging and their role throughout the food chain (Appendini and Hotchkiss, 2002, Kerry et al. 2006, Realini and Marcos, 2014, Fang et al. 2017, PoyatosRacionero et al. 2018). This paper will focus on packaging systems that can have a direct impact on food waste at the household level and consider active and also intelligent packaging, sometimes called dynamic packaging or "smart" packaging.

\subsection{Active packaging}

Active packaging has the advantage of allowing food companies to extend shelf-life and still maintain product quality. With features such as moisture control, absorption of liquid or oxygen, or the release of preservatives and other forms of shelf-life extension, active packaging has a functionality whereby the product, the packaging and the external environment interact to modify the condition of the packed material including its innate microbiological safety (Vermeiren et al. 1999; Fang et al. 2017; Manning, 2018). There are many types of active packaging technologies that include:

- Addition of sachets/pads containing volatile antimicrobial agents into packages;

- Incorporation of volatile and non-volatile antimicrobial agents directly into polymers;

- Coating or adsorbing antimicrobials onto polymer surfaces;

- Immobilisation of antimicrobials to polymers by ion or covalent linkages; and

- Use of polymers that are inherently antimicrobial (Appendini and Hotchkiss, 2002).

Active packaging technology has been used in various food sectors including meat (Appendini and Hotchkiss, 2002; Kerry et al. 2006; Fang et al. 2017, Poyatos-Racionero et al. 2018); pastry products (Appendini and Hotchkiss, 2002; Gutierrez et al. 2017; Poyatos-Racionero et al. 2018) and fruits and vegetables (Appendini and Hotchkiss, 2002, Poyatos-Racionero et al. 2018).

\subsection{Intelligent Packaging}


Intelligent Packaging is "a packaging system that is capable of carrying out intelligent functions (like detecting, sensing, recording, tracing, communicating, and applying scientific logic) to facilitate decision making, to extend shelf-life, enhance safety, improve quality, provide information, and warn about possible problems" (Yam et al. 2005). Alternatively, intelligent packaging is considered as packaging which contains sensors or indicators in order to monitor condition of food during its life cycle to communicate information related to the quality of the product. (Heising et al. 2014). There are multiple types of "smart devices" that can be used in intelligent packaging (Table 2) and their functions have been explored by multiple studies (Realini and Marcos, 2014; Zhang et al. 2016; Fang et al. 2017; Poyatos-Racionero et al. 2018). With regard to intelligent packaging, it is important to distinguish between a sensor and an indicator. A sensor measures certain criteria and has to be connected to a separate device, whilst an indicator integrates measurement and the provision of qualitative or semi-quantitative information about quality through a visible change (Heising et al. 2014).

\section{Take in Table 2}

Intelligent systems in food packaging can incorporate external discrete components in the final pack with examples being either two dimensional (2D) films or three dimensional (3D) objects (Ghaani et al. 2016). These technologies include:

1. Sensors (chemical or biosensors) which identify analytes in food;

2. Indicators that identify to the consumer the presence/absence or level of a substance, or a reaction that has occurred e.g. time temperature changes, gas indicators;

3. Thermochromatic or photochromatic inks that act as indicators by changing colour within a certain temperature range;

4. Electronic article surveillance (EAS) anti-counterfeiting, anti-tamper and anti-theft devices such as holograms, micro-tags, tear labels and tapes; and 
5. Data carriers that carry information for theft protection or counterfeit protection e.g. 1D, 2D and QR 2D barcodes and radio-frequency identification (RFID) tags (Han et al. 2005; Kerry et al. 2006; López-Gómez et al. 2015; Ghaani et al. 2016; Manning, 2017). Intelligent packaging linked to sensors can inform the use of IoT technology (Yang et al. 2014) and also reduce food waste (Noletto et al. 2015). Intelligent packaging technologies can indicate signs of leakage (López-Gómez et al. 2015), or the presence of glucose, ethanol, volatile gases e.g. amines in fish, bacterial content, colour degradation etc. (Pal and Kant, 2018). Multiple time-temperature indicators (TTI) have been developed into labels that can be used on packaging (López-Gómez et al. 2015). However, a lack of knowledge of intelligent packaging and IoT and the cost of implementation is the greatest barrier to technology implementation (Noletto et al. 2015). Along with the development of intelligent packaging, smart mobile devises and the associated apps, there has been the development of intelligent fridges (Vanderroost et al. 2017) and this is now considered in more detail.

\subsection{Intelligent Fridges}

Features of fridges that users appreciate are visual aesthetics, size, colour, practicality and usefulness, reliability and efficiency and ease of cleaning (Cotrim, 2016). However an additional solution to reducing household food waste by improving product storage and household inventory management has also emerged in recent years: the intelligent or "smart" fridge. Indeed, since the 1990s, research has been carried out to develop a refrigerator that can actively address the contemporary challenge of food waste (Hebrok and Boks, 2017). Intelligent fridges are appliances where their functionality has been extended to include: measuring the internal environmental conditions of the fridge and regulating the environment to optimise storage conditions; manage supply activities and shopping lists; detecting and monitoring food packages and their content; alerting retailers and consumers about expiration dates, and suggesting recipes to consumers with the food products or packages stored in the fridge 
(Vanderroost et al. 2017). Therefore an intelligent fridge could provide consumers with updated knowledge of the status of stock in the fridge via the use of barcodes or RFID technology i.e. what is about to expire in the fridge and needs to be used (Osisanwo et al. 2015). If such intelligent applications are integrated into household routines they could address the causes of food waste cited in the literature including food storage, planning, shopping, preparation and consumption (Hebrok and Boks, 2017). Beyond providing information to consumers, it is therefore possible to reduce food waste by improving or facilitating data processing as part of an intelligent application within the household. This approach lends itself to the concept of the enabled "Smart Home" (Deokar et al. 2018), who argue that there is no standard definition of the concept, but the objective is to improve resource use, increase service provision to householders whilst also reducing operational costs. Smart homes (a form of smart systems) allow people to connect with and control their home appliances from remote locations (Minaam et al. 2018). Smart home is not a new term. Fifteen years ago, Aldrich (2003:17) defined a smart home as "a residence equipped with computing and information technology which anticipates and responds to the needs of the occupants, working to promote their comfort, convenience, security and entertainment through the management of technology within the home and connections to the world beyond." Studies have considered a range of intelligent household devices including: domestic heating, fridges, cookers/ovens, washing machines, and televisions (Mogali, 2015; Singh and Jain, 2016) and these devices can also link to wearable devices and e-health systems (Minaam et al. 2018). Research has considered the barriers to the adoption and diffusion of smart home systems. These include social barriers such as cost, control, privacy and trust dynamics (Balta-Ozkan et al. 2013); time and effort required to learn how to use the technologies (Chan et al. 2009), and that people value technology that saves time and makes household tasks easier but not at the expense of feeling comfort, relaxation and sentiment (Haines et al. 2007) i.e. what it is to be a "home". 
Consideration of the "Smart Home" can also reflect on what it is to be a "Smart Kitchen". The Smart Kitchen has been described as an instrumented environment to automatically capture, share and exploit data (Deokar et al. 2018) via technology such as liquid crystal display (LCD), RFID tags sensors and actuators, quick response (QR) codes, big data analysis, wireless sensor networks (WSD), cloud computing, broadband applications and nanotechnologies (Mogali, 2015; Chatterjee et al. 2018; Khan, 2018; Minaam et al. 2018). The Smart Kitchen as a concept is worthy of wider investigation, especially in terms of assisted living for the elderly (Blasco et al. 2014), improving knowledge and its applicability via improved cooking skills (Hashimoto et al. 2008), cooking and being calorie-aware (Chi et al. 2008) and interaction with features of intelligent packaging (Yam, 2000; Yam et al. 2005), but here we consider the applicability specifically in terms of reducing household food waste (Minaam et al. 2018). Thus an intelligent fridge can not only contain the aforementioned functional features, but also identify buying patterns, speech recognition (Rouillard, 2012), enable control of other IoT items not in the fridge, and aiding the cleaning of the fridge too (Cotrim, 2016). The timeline for the development of intelligent fridges has been explored highlighting features and applications (Table 3).

\section{Take in Table 3}

The components of an intelligent fridge within the context of the IoT include:

- an individual IP address that allows the fridge to receive information from a server via the internet and allows a user terminal e.g. on a smart phone to access the fridge;

- a control unit or microcontroller to manage the functions of the fridge;

- the sensor devices that measure criteria such as temperature and humidity and then convert the measurements into signals that can be read and interpreted by the control unit(s); and 
- the communication devices with embedded electronics that interact either wirelessly or through wired networks with other IoT devices and appliances to transform information received to radio waves or signals. Bluetooth or WiFi or RFID technology may be used. If RFID is used then a RFID antenna is installed within the fridge to recognise the data contained within the RFID tag on each product e.g. shelf-life data (Osisanwo et al. 2015).

However, RFID technologies require the embedding of RFID tags on every product which is expensive (Bonaccorsi et al. 2017). The equipment itself is expensive, which again is a barrier to adoption with units ranging in the UK depending on size from $£ 1800$ to $£ 3800$ per appliance (currys.co.uk, nd). Thus whilst there are benefits in terms of reducing food waste through the use of smart technology, comparing the cost of the appliance to the annual household cost of food waste in the WRAP (2009) study of $£ 480$ per year shows that the units will have to reduce in price substantially for there to be an economic incentive to increase purchase of intelligent fridges. The benefits and concerns associated with intelligent fridges include on the benefits side remote access especially from smart phones, innovative management of food to reduce household food waste, convenience and monitoring to ensure effective management of the fridge and an opportunity for more effective product recall (Osisanwo et al. 2015). Vulnerabilities that create concern include: hacking and the risk of cyber-attacks, unwanted interaction with manufacturers and concerns over privacy, security and data ownership (Osisanwo et al. 2015; Prapulla et al. 2015; Minaam et al. 2018). Weak elements in some appliances can allow hackers to place malware on the appliance and to attack the whole IoT home system. Between late 2013 and early 2014 hackers accessed 100,000 home appliances including fridges, televisions, wireless speakers and media centres, and then used the appliances to release around 750,000 malicious emails (Zimmerman, 2015). There are further challenges associated with poor internet connectivity and low internet speeds in some areas, and a lack of 
uniformity with barcodes that link to expiration dates and the high cost of appliances (Prapulla et al. 2015). It is also difficult to create IoT systems if the proposed system is too complex, and factors such as multiple programming languages and communication protocols and an absence of common guidelines have not been addressed (Minaam et al. 2018). Food recognition within a smart fridge relies on a database of logos and text on packaging and subsequent identification by the use of cameras of items in the fridge and this can be affected by point-of-view constraints within the appliance (Bonaccorsi et al. 2017). Khan (2018) proposes a novel cloud-based smart expiry system that sends automatic notifications to a smartphone or IoT device as a means to reduce household food waste. This approach could link the scanning information at the retail checkout to a smartphone app so manual entry is not required, or the use of enabled fridge magnets that can scan QR codes and this is being considered at the prototype stage.

The literature cites multiple problems relating to current systems of food date coding and the influence on household food waste in particular their interpretation and degree of understanding by consumers (Rahelu, 2009, Quested et al. 2011; Mena et al. 2014; Newsome et al. 2014; O'Connor et al. 2014; van Boxstael et al. 2014; Osborn, 2016; Hall-Phillips and Shah, 2017; Wilson et al. 2017, Schanes et al. 2018 among others). The intelligent or smart fridge offers a wide range of tools and equipment to help manage food, but there is a risk, especially with the high purchase cost compared to standard fridges that the consumer will characterise it as an "unnecessarily expensive gadget". However due to the various advantages, particularly in terms of managing stock control and as a result reducing food waste, the intelligent fridge has gained interest both in the literature, contemporary research and in the industry. Few studies have considered the degree of consumer acceptability and interest in intelligent approaches to reducing household food waste such as interactive packaging and intelligent fridges. Thus empirical research is required in this area.

\section{Discussion}


Food waste is a growing problem requiring interventions at all levels of the food supply chain. In developed countries interventions are specifically required to reduce household food waste. Multiple factors have been identified that contribute to household food waste including a lack of understanding by consumers of durability coding and expiration dates on food. These systems have developed over time and evolved into static date coding on packaging, but with the advent of new technologies and applications a smarter approach can be used at consumer level. The length of shelf-life influences food waste with a longer shelf-life leading to less waste. Whilst preservatives extend shelf-life, the trend towards "clean labels" means that alternative intelligent approaches may need to be considered to minimise food waste and deliver effective household inventory management. These approaches must meet the expectations of consumers, increase personal agency over food waste by improving product storage conditions and informing purchasing behaviour

Some food ingredients such as preservatives or additives are perceived by consumers as unhealthy (Asioli et al. 2017) even if they effectively and consistently deliver safe food. One option for delivering "clean labels" and reduce food additives is to use herbs and spices that have food preservation attributes as they can be labelled as spices or natural flavours on packaging (Embuscado, 2015). The drive for "clean label" foods means that the cues on the front-of-pack (FOP) and back-of-pack (BOP) take on both objective and subjective characteristics i.e. an ingredients list or nutrition panel can objectively define a the physiochemical composition of the food but claims or logos (such as free from, organic, natural) can provide a more subjective, perception based assessment of whether as food is clean (Asioli et al. 2017). Thus the use of active packaging with "natural" additives may be of value in reducing food waste and still maintain a clean label approach. Positive consumer perceptions of active packaging may focus on convenience and safety whilst negative reactions may focus on naturalness of interaction with the food, packaging cost, the degree of recyclability of complex 
packaging, a lack of trust in industry and science and the latter may be a barrier to long-term uptake of new technology (Werner et al. 2017). Intelligent packaging too may have some consumer perception issues regarding recyclability. Aliaga et al. (2011) report that the presence of RFID tags will influence the ability to recycle plastic packaging although printed electronics will have better recyclability. Printed electronics using functional inks will change the production of electronic devices such as RFID tags, displays, sensors on flexible packaging substrates via ink-jet, screen and gravure printing (Vanderroost et al. 2014). Thus low-cost chipless RFID sensors are now being developed (Feng et al. 2015; Wittkopf et al. 2018). Indeed, Wittkopf et al. (2018) argue that: "Chipless RFIDs are a disruptive technology that acts as a moderate solution between conventional barcodes and chipped RFIDs. These devices allow for cost savings compared to chipped RFIDs and can be identified even with an obstructed view of the tag" and are thus of value in future intelligent packaging applications. Milmo (2018) states that costs of such smart technology has reduced to around $\$ 0.10$ per pack, but as technology improves further this cost will further reduce.

Intelligent packaging offers a clear and quick tool via for example change of colour of ink or on sensors which reduces the risk of misinterpretation. Intelligent packaging also has an increasing role in developing traceability and trust in the food supply chain. Distributed ledger technology, such as Blockchain, can be applied as an approach to integrate data across supply chain food safety management systems using inputs from temperature sensors, global positioning systems (GPS) locators, video cameras, RFID, barcodes or QR codes, and integrating this with product analytical test data, assurance data and site certification information relating to foodstuffs, their packaging, and location (Manning and Wareing, 2018). The use of intelligent applications to extend shelf-life, aid food safety, traceability and as part of a smart kitchen approach via the "smart fridge" has been explored. 
Intelligent fridges have been developed for several decades and over that time their functionality has improved and diversified. In view of the growing interest in finding a solution to consumer food waste, appliance manufacturers have focused on food management options for stock control (date management and storage conditions) and wider food handling behaviour such as purchasing and cooking. Barriers have been identified to the adoption and diffusion of smart home systems including: cost, control, security, hacking, cyber-attacks and privacy, data ownership and the nature of the interaction with manufacturers and wider trust dynamics (BaltaOzkan et al. 2013; Osisanwo et al. 2015; Prapulla et al. 2015; Minaam et al. 2018); the time and effort required to learn how to use the technologies (Chan et al. 2009), and how the technologies influence the aesthetic concept of a home (Haines et al. 2007). Thus in positioning the use of intelligent applications to reduce food waste, whilst clear benefits can be identified, negative impacts must also be considered. The IoT can provide synergistic benefits by connecting people, products, appliances and data and enabling data informed decision-making (DíazNafría and Guarda, 2017). However many users of IoT applications may not fully recognise the pervasiveness of data transactions, as they are largely invisible and whilst some communities can take full advantage of the benefits those who do not have access can become more disadvantaged (Pereira et al. 2013). The success of intelligent appliances to reduce food waste and to gain the degree of household coverage required will depend not only on the functional elements of design and as a result the cost of the equipment, but also on the transparency and trust dynamics of factors such as data use and the protection of privacy, informed consent, and how over time the IoT does or does not inform personal agency and autonomy. Chaudhuri (2017) states that there is the potential to delegate human autonomy and agency to things but the benefit may be to increase consumer experience of specific properties and experiences (Hoffman and Novak, 2018). Further others may argue that pro-social nudging or choice architecture, whilst reducing autonomy and choice, may be appropriate if it leads to the greater 
good, i.e. a reduction in consumer food waste, financial savings for individual families and an 496 overall benefit for society.

\section{Conclusion}

498

499

500

501

502

503

504

505

506

507

508

509

510

511

This work has considered the role of intelligent applications such as intelligent packaging, intelligent fridges and wider IoT solutions to reduce household food waste. These technologies provide opportunities, albeit at a cost, to extend shelf-life and to move the communication of duration and product life from static coding system to more dynamic applications. This can be achieved either through active packaging solutions or through IoT systems in a smart-enabled kitchen environment. Whilst intelligent applications have the opportunity to reduce consumer food waste, as outlined in this paper there are some negative impacts that also need to be considered such as data privacy, the risk of hacking and concerns over whether the opportunity for informed agency will have an impact on actual behaviour in the home, when purchasing or planning food consumption. Further research should be undertaken to explore the sociotechnical issues that arise in this paper and how they can be addressed to minimise household food waste. 


\section{References}

Acho, F., Zoué, L., Adom, N. and Niamké, S., 2015. Impact of freezing processing on nutritive and antioxidant properties of leafy vegetables consumed in Southern Côte d'Ivoire. Ukrainian Food Journal, 4(3), pp.467-480

Aldrich, FK. "Smart homes: past, present and future." In Inside the smart home, pp. 17-39. Springer, London, 2003.

Aliaga, C., B. M.Ferreira, M. Hortal, M., Á., Pancorbo, J.M. López, \& F.J. Navas, (2011). Influence of RFID tags on recyclability of plastic packaging. Waste management, 31(6), 1133-1138.

Appendini, P. and J.H. Hotchkiss, 2002. Review of antimicrobial food packaging. Innovative Food Science \& Emerging Technologies, 3(2), 113-126.

Armouche, 2014. Le séchage - Les modifications physicochimiques. Génie Alimentaire. [online] http://genie-alimentaire.com/spip.php?article149 [Assessed 18 October 2018]

Armouche, 2010. La congelation \& surgélation. Génie Alimentaire. [on-line] Available at: http://genie-alimentaire.com/spip.php?article11 [Assessed 18 October 2018]

Asaria, P., D. Chisholm, C. Mathers, M. Ezzati, and R. Beaglehole, 2007. Chronic disease prevention: health effects and financial costs of strategies to reduce salt intake and control tobacco use. The Lancet, 370(9604), pp.2044-2053.

Asioli, D., J. V. Aschemann-Witzel, R. Caputo, A. Vecchio, T. Annunziata, T. Næs, and P. Varela, 2017. Making sense of the "clean label" trends: A review of consumer food choice behavior and discussion of industry implications. Food Research International, 99, 58-71.

Axel, C., E. Zannini, and E.K. Arendt, 2017. Mold spoilage of bread and its biopreservation: A review of current strategies for bread shelf life extension. Critical reviews in food science and nutrition, 57(16), 3528-3542.

Bacenetti, J., A. Cavaliere, G. Falcone, V. Giovenzana, A. Banterle, and R. Guidetti, 2018. Shelf life extension as solution for environmental impact mitigation: A case study for bakery products. Science of The Total Environment, 627, 997-1007

Balta-Ozkan, N., R. Davidson, M. Bicket, and L. Whitmarsh, 2013. Social barriers to the adoption of smart homes. Energy Policy, 63, 363-374.

Béné N., 2009. Les méthodes de conservation des aliments du XIXe siècle à nos jours. Available at: https://www.doc-developpement-durable.org/file/Conservation-GrainesSemences-Vegetaux-Legumes-Refrigeration/methodes-de-conservation-des-aliments.pdf \{Accessed 26 October 2018]

Blasco, R., Á. Marco, R. Casas, D. Cirujano, and R. Picking, 2014. A smart kitchen for ambient assisted living. Sensors, 14(1), 1629-1653.

Blondin, S.A., H.C. Djang, N. Metayer, S. Anzman-Frasca, S. and C.D. Economos, 2015. 'It's just so much waste.'A qualitative investigation of food waste in a universal free School Breakfast Program. Public health nutrition, 18(9), 1565-1577. 
Bonaccorsi, M., S. Betti, G. Rateni, D. Esposito, A. Brischetto, M. Marseglia, P. Dario, and F. Cavallo, 2017. 'HighChest': An Augmented Freezer Designed for Smart Food Management and Promotion of Eco-Efficient Behaviour. Sensors, 17(6), 1357-78.

Brigand G. C. Chaumontet, P. Guion, H. Hoellinger, H. Leroux, P. Manchon, P., Martelm, H. Nordmann, G. Pascal, R. Rizzoth, G. de Saint-Blanquat, C. Servoz, and P. Verger, 1998, LES ADDITIFS, dossier scientifique de l'IFN $n^{\circ} 10$ Available at: http://alimentation-sante.org/wpcontent/uploads/2011/07/dossier-scient-10.pdf [Accessed 26 October 2018]

Buttriss, J.L. 2013. Food reformulation: the challenges to the food industry. Proceedings of the Nutrition Society, 72(1), 61-69.

Buzby, J.C. and J. Hyman, 2012. Total and per capita value of food loss in the United States. Food Policy, 37(5), 561-570.

Ceuppens, S., S. Van Boxstael, A. Westyn, F. Devlieghere, and M. Uyttendaele, 2016. The heterogeneity in the type of shelf life label and storage instructions on refrigerated foods in supermarkets in Belgium and illustration of its impact on assessing the Listeria monocytogenes threshold level of 100 CFU/g. Food Control, 59, 377-385.

Chan, M., E. Campo, D, Estève, and J.Y. Fourniols, 2009. Smart homes-current features and future perspectives. Maturitas, 64(2), 90-97.

Chatterjee, J.M., Kumar, R., Khari, M., Hung, D.T. and Le, D.N., 2018. Internet of Things based system for Smart Kitchen. I.J Engineering and Manufacturing, 4, 29-39

Chaudhuri, A. 2017. Philosophical Dimensions of Information and Ethics in the Internet of Things (IoT) Technology. EDPACS, 56(4), 7-18.

Chi, P.Y.P., J.H. Chen, H.H. Chu, and J.L. Lo, 2008, June. Enabling calorie-aware cooking in a smart kitchen. In International Conference on Persuasive Technology (pp. 116-127). Springer, Berlin, Heidelberg.

Codex Alimentarius 1999. Code of Hygienic Practice for Refrigerated Packaged Foods with Extended Shelf Life. CAC/RCP 46-(1999)

Coleman-Jensen, A., C. Gregory, and A. Singh, 2014. Household Food Security in the United States in 2013 (September 1, 2014). USDA-ERS Economic Research Report Number 173. Available at SSRN: http://dx.doi.org/10.2139/ssrn.2504067

Cotrim, C.A. 2016. Savvy ware. Smart system for food management in the household environment. Final Thesis for M.Sc. Design \& Engineering Scuola di Design Politecnico de Milano. Milan.

Currys (nd) On-line retail store. Available at: https://www.currys.co.uk/gbuk/index.html [Accessed: 03 December 2018]

DEFRA, 2011, Guidance on the application of date labels to food, Available at: http://www.reading.ac.uk/foodlaw/label/dates-defra-guidance-2011.pdf [Accessed: 18 October 2018] 

INNOVATIVE WAY TO COOK. International Research Journal of Engineering and Technology (IRJET), 5(03), 2395-0056.

Díaz-Nafría, J. M., and T. Guarda, (2017, June). Is the Internet-of-Things a Burden or a Leverage for the Human Condition?. In Multidisciplinary Digital Publishing Institute Proceedings 1(3), 240).

Duchene, C. and G. Gandemer, 2017. Raw meat, cooked meat: The effects of cooking on meat nutritional values. CAHIERS DE NUTRITION ET DE DIETETIQUE, 52(3), 134-149.

Embuscado, M.E. 2015. Spices and herbs: Natural sources of antioxidants-a mini review. Journal of Functional Foods, 18, 811-819.

European Parliament, 2017. European Parliament resolution of 16 May 2017 on initiative on resource efficiency: reducing food waste, improving food safety (2016/2223(INI)).

Fang, Z., Y. Zhao, R.D. Warner, and S.K. Johnson, 2017. Active and intelligent packaging in meat industry. Trends in food science \& technology, 61, pp.60-71

FAO. 2011, Extent, causes and prevention. Rome: Food and Agriculture Organization of the United Nations.

Feng, Y., L. Xie, Q. Chen, and L.R. Zheng, 2015. Low-cost printed chipless RFID humidity sensor tag for intelligent packaging. IEEE Sensors Journal, 15(6), 3201-3208.

Fournier P. (nd). ALIMENTS conservation des - (repères chronologiques). Encyclopaedia Universalis [on-line] Available at: http://www.universalis.fr/encyclopedie/aliments-repereschronologiques/ [Accessed: 18 October 2018]

Gac, A., 1992. Les industries agro-alimentaires et la chaîne du froid. International journal of refrigeration, 15(1), 6-9

Gaiani, S., S. Caldeira, V. Adorno, A, Segrè, and M. Vittuari, 2018. Food wasters: Profiling consumers' attitude to waste food in Italy. Waste Management, 72, 17-24.

Garrone, P., M. Melacini, and A. Perego, 2014. Surplus food recovery and donation in Italy: the upstream process. British Food Journal, 116(9), 1460-1477.

Ghaani, M., C.A. Cozzolino, G. Castelli, and S. Farris, 2016, An overview of the intelligent packaging technologies in the food sector, Trends in Food Science and Technology, 51, 1-11

Gibis, M., 2016. Heterocyclic aromatic amines in cooked meat products: causes, formation, occurrence, and risk assessment. Comprehensive Reviews in Food Science and Food Safety, 15(2), 269-302.

Griffin, M., J. Sobal, and T.A. Lyson, 2009. An analysis of a community food waste stream. Agriculture and Human Values, 26(1-2), 67-81

Gutierrez, M.M., M. Meleddu, and A. Piga, 2017. Food losses, shelf life extension and environmental impact of a packaged cheesecake: A life cycle assessment. Food Research International, 91, 124-132. 
Haines, V., V. Mitchell, C. Cooper, and M. Maguire, 2007. Probing user values in the home environment within a technology driven Smart Home project. Personal and Ubiquitous Computing, 11(5), 349-359.

Han, J. H., C.H.L. Ho, and E.T. Rodrigues, 2005. Intelligent packaging. In J. H. Han (Ed.), Innovations in food packaging (p. 151). Amsterdam: Ed. Elsevier Academic Press.

Hall-Phillips, A. and P. Shah, 2017. Unclarity confusion and expiration date labels in the United States: A consumer perspective. Journal of Retailing and Consumer Services, 35, 118126

Hashimoto, A., N. Mori, T. Funatomi, Y. Yamakata, K. Kakusho, and M. Minoh, 2008. Smart kitchen: A user centric cooking support system. In Proceedings of IPMU 8, 848-854.

Hayat, O., 2016. Modes de conservation de l'antiquité à nos jours. [on-line] Available at: http://blog.ac-versailles.fr/conservationalimentsmeef/index.php/post/10/12/2016/Modes-deconservation-des-aliments-durant-l-antiquit\%C3\%A9 [Accessed 26 October 2018]

Hebrok, M. and C. Boks, 2017. Household food waste: Drivers and potential intervention points for design-An extensive review. Journal of Cleaner Production, 151, 380-392

Heising, J. K., M. Dekker, P.V. Bartels, and M.A.J.S Van Boekel, 2014. Monitoring the quality of perishable foods: opportunities for intelligent packaging. Critical reviews in food science and nutrition, 54(5), 645-654

Henderson, G., 2004. 'Free' food, the local production of worth, and the circuit of decommodification: A value theory of the surplus. Environment and Planning D: Society and Space, 22(4), 485-512.

Hendriksen, M.A., J.M. Geleijnse, J.M. Van Raaij, F.P. Cappuccio, L.C. Cobiac, P. Scarborough, W.J. Nusselder, A. Jaccard, and H.C. Boshuizen, 2017. Identification of differences in health impact modelling of salt reduction. PloS one, 12(11), 0186760.

Hoffman, D. L., and T.P. Novak, 2017. Consumer and object experience in the internet of things: An assemblage theory approach. Journal of Consumer Research, 44(6), 1178-1204.

Hogg, D., J. Barth, K. Schleiss, and E. Favoino, 2007. Dealing with Food Waste in the UK. Report for WRAP. Eunomia Research \& Consulting.

Hou, C., N. Kang, C. Schlosser, M. Zhao, Z. Wang, and D. Zhang, 2018. Heterocyclic aromatic amines in commercial Chinese dried meat products. Journal of Food \& Nutrition Research, 57(2) 151-160

Inguglia, E. S., Z. Zhang, B.K. Tiwari, J.P. Kerry, and C.M. Burgess, 2017. Salt reduction strategies in processed meat products-A review. Trends in Food Science \& Technology, 59, 7078.

Kerry, J.P., M.N. O'Grady, and S.A. Hogan, 2006. Past, current and potential utilisation of active and intelligent packaging systems for meat and muscle-based products: A review. Meat science, 74(1), pp.113-130

Khan, T. 2018. Cloud-based architecture of a smart expiry system with IoT device,

Development, 5(4), 641-650 
664

665

666

667

668

669

670

671

672

673

674

675

676

677

678

679

680

681

682

683

684

685

686

687

688

689

690

691

692

693

694

695

696

697

698

699

700

701

702

703

Krifa, F., A. Aissa, M. Jerray, M. Kallel, and J. Alary, 1990. A clinical-study of the impact on consumer health of dyes used in Tunisia. Revue francaise d'allergologie et d'immunologie clinique, 30(1), 7-15.

López-Gómez, A., F. Cerdán-Cartagena, J. Suardíaz-Muro, M. Boluda-Aguilar, M.E. Hernández-Hernández, M.A. López-Serrano, and J. López-Coronado, 2015. Radiofrequency identification and surface acoustic wave technologies for developing the food intelligent packaging concept. Food engineering reviews, 7(1), 11-32

Lundqvist, J., C. de Fraiture and D. Molden, 2008. Saving water: from field to fork: curbing losses and wastage in the food chain. Stockholm: Stockholm International Water Institute.

Maillot, M., L. Privet, S. Vaudaine, A. Lluch, and N. Darmon, 2017. Enfants et adultes forts consommateurs de sucres libres en France: quels changements alimentaires pour respecter les recommandations nutritionnelles?. Cahiers de Nutrition et de Diététique, 52, S66-S79.

Manning, L. 2017. Traceability: An essential mechanism to underpin food integrity Contemporary issues in food supply chain management. Eastham et al. Goodfellow Publishers Ltd

Manning, L., 2018. Guide to Good Manufacturing Practice. Institute of Food Science and Technology, 7th Edition - Manning, L. Eds. Wiley ISBN-978-1119388449 10th August 2018. Chapter 25 p 202

Manning, L. and P. Wareing, 2018. Evolving risk management systems, Food Science and Technology Journal 32(3) Available at: https://www.fstjournal.org/features/32-3/riskmanagement-systems

Mena, C., B. Adenso-Diaz, and O. Yurt, 2011. The causes of food waste in the supplierretailer interface: Evidences from the UK and Spain. Resources, Conservation and Recycling, 55(6), 648-658

Mena, C., L.A. Terry, A. Williams and L. Ellram, 2014. Causes of waste across multi-tier supply networks: Cases in the UK food sector. International Journal of Production Economics, 152, pp.144-158

Milne, R., 2012. Arbiters of waste: date labels, the consumer and knowing good, safe food. The Sociological Review, 60(2_suppl), 84-101.

Milmo, S. 2018. Showing the value of smart packaging. Available at: https://www.printedelectronicsnow.com/issues/2018-03-01/view_features/showing-the-valueof-smart-packaging/ [Accessed 02 December 2018]

Ministère de l'agriculture et de l'alimentation, 2014. Vers l'alimentation moderne : histoire de l'industrie agroalimentaire. Alim'agri, [on-line] Available at: http://agriculture.gouv.fr/verslalimentation-moderne-histoire-de-lindustrie-agroalimentaire [Accessed 26 October 2018]

Minaam, D.S.A., M. Abd-ELfattah and M.A. Ali, 2018. Design of an Internet of Things (IoT) network system for Kitchen food waste management. IJCSNS, 18(5), 130. 
Mogali, S.S. 2015. Internet of Things and its role in Smart Kitchen. 4th National Conference of Scientometrics and Internet of Things, Bangalore.

Møller, H., O.J. Hanssen, J. Gustavsson, K. Östergren, Å. Stenmarck, and P. Dekhtyar, 2014. Report on review of (food) waste reporting methodology and practice. Ostfold Research, Norway.

Neff, R.A., M.L. Spiker and P.L. Truant, 2015. Wasted food: US consumers' reported awareness, attitudes, and behaviors. PloS one, 10(6), 0127881.

Nellman, C., M. MacDevette, T. Manders, B. Eickhout, B. Svihus and A.G. Prins, 2009. The environmental food crisis-The environment's role in averting future food crises. A UNEP Rapid Response. United Nations Environment Programme, GRID-Arendal, Norway

Newsome, R., C.G. Balestrini, M.D. Baum, J. Corby, W Fisher, K. Goodburn, T.P. Labuza, G. Prince, H.S. Thesmar and F. Yiannas, 2014. Applications and perceptions of date labeling of food. Comprehensive Reviews in Food Science and Food Safety, 13(4), 745-769.

Noletto, A. P. R., S.A. Loureiro, R.B. Castro and O.F.L. Júnior, 2017. Intelligent Packaging and the Internet of Things in Brazilian Food Supply Chains: The Current State and Challenges. In Dynamics in Logistics (173-183). Springer, Cham

O'Connor, C., M. Gheoldus and O. Jan, 2014. Comparative study on EU Member States' legislation and practices on food donation. European Economic and Social Committee in Collaboration with Deloitte SA: Brussels, Belgium.

Osborn, S 2016. Wastage of Food Reference Module in Food Science, Encyclopedia of Food and Health 2016, 447-452

Osisanwo, F., S. Kuyoro, and O. Awodele, 2015. Internet refrigerator-A typical internet of things (IoT). In 3rd International Conference on Advances in Engineering Sciences \& Applied Mathematics (ICAESAM'2015), London (UK). http://iieng. org/images/proceedings_pdf/2602E0315051.pdf. [Accessed 27 October 2018]

Pal, A., and K. Kant, 2018. IoT-Based Sensing and Communications Infrastructure for the Fresh Food Supply Chain. Computer, 51(2), 76-80

Pereira, Â. G., A. Benessia, and P. Curvelo, 2013. Agency in the Internet of Things. Luxembourg: Publication office of the European Union. Available at: https://core.ac.uk/download/pdf/38627181.pdf [Accessed 28 October 2018]

Ponis, S.T., P.A. Papanikolaou, P. Katimertzoglou, A.C. Ntalla, and K.I. Xenos, 2017. Household food waste in Greece: A questionnaire survey. Journal of Cleaner Production, $149,1268-1277$.

Poyatos-Racionero, E., J.V. Ros-Lis, J.L. Vivancos and R. Martinez-Manez, 2018. Recent advances on intelligent packaging as tools to reduce food waste. Journal of Cleaner Production, 172, 3398-3409

Prapulla, S. B., G. Shobha, and T.C. Thanuja, 2015. Smart refrigerator using internet of things. Journal of Multidisciplinary Engineering Science and Technology, 2(1), 1795-1801.

Rahelu, K., 2009. Date labelling on food. Nutrition bulletin, 34(4), 388-390 
Realini, C.E. and B. Marcos, 2014. Active and intelligent packaging systems for a modern society. Meat science, 98(3), 404-419

Regan, Á., M.P. Kent, M.M. Raats, Á. McConnon, P. Wall, and L. Dubois, 2017. Applying a consumer behaviour lens to salt reduction initiatives. Nutrients, 9(8), 901.

Regulation (EU) No 1169/2011 of the European Parliament and of the Council of 25 October 2011 on the provision of food information to consumers, amending Regulations (EC) No 1924/2006 and (EC) No 1925/2006 of the European Parliament and of the Council, and repealing Commission Directive 87/250/EEC, Council Directive 90/496/EEC, Commission Directive 1999/10/EC, Directive 2000/13/EC of the European Parliament and of the Council, Commission Directives 2002/67/EC and 2008/5/EC and Commission Regulation (EC) No 608/2004 Text with EEA relevance OJ L 304, 22.11.2011, p. 18-63

Ricci, A., A. Allende, D. Bolton, M. Chemaly, R. Davies, P.S Fernández Escámez, R. Girones, L. Herman, K. Koutsoumanis, B. Nørrung, L. Robertson, G. Ru, M. Sanaa, M. Simmons, P. Skandamis, E. Snary, N. Speybroeck, B. Ter Kuile, J. Threlfall, H. Wahlstrom, J. Takkinen, M. Wagner, D. Arcella, M.T. Da Silva Felicio, M. Georgiadis, W. Messens and R. Lindqvist, 2018. Listeria monocytogenes contamination of ready-to-eat foods and the risk for human health in the EU. EFSA Journal, 16(1). 173 pages Adopted 6 December 2017

Romani, S., S. Grappi, R.P. Bagozzi and A.M. Barone, 2018. Domestic food practices: A study of food management behaviors and the role of food preparation planning in reducing waste. Appetite, 121, 215-227.

Romanazzi, G., Feliziani, E., Baños, S.B. and Sivakumar, D., 2017. Shelf life extension of fresh fruit and vegetables by chitosan treatment. Critical reviews in food science and nutrition, 57(3), 579-601.

Rooney, M. 1992 Reactive Packaging Materials for Food Preservation. In: Proceedings of the First Japan-Australia Workshop on Food Processing, Tsukuba, Japan, 78-82.

Rooney, M.L. 2012 Active Food Packaging, Springer US ISBN 9781461359104

Rotfeld, H.J., 2009. Health information consumers can't or don't want to use. Journal of Consumer Affairs, 43(2), 373-377

Rouillard, J. 2012. The Pervasive Fridge. A smart computer system against uneaten food loss. In Seventh international conference on systems (ICONS2012) February 2012. 135.

Quested, T., and A. Parry, 2011. New estimates for household food and drink waste in the UK. Oxon, Waste \& Resources Action Programme (WRAP).

Quested, T.E., A.D. Parry, S. Easteal and R. Swannell, 2011. Food and drink waste from households in the UK. Nutrition Bulletin, 36(4), 460-467.

Sadecka, J., M. Polovka, E. Kolek, E. Belajova, B. Tobolkova, L. Dasko and J. Durec, 2014. Orange juice with pulp: impact of pasteurization and storage on flavour, polyphenols, ascorbic acid and antioxidant activity. Journal of Food \& Nutrition Research, 53(4), 371-388

SANTE/2016/E1/024 - Market study on date marking and other information provided on food labels and food waste prevention Available at: https://ec.europa.eu/food/sites/food/files/safety/docs/fw_eu_actions_tech-specs_2016-e1024_annex2.pdf [Accessed 26.10.18] 
Schanes, K., K. Dobernig and B. Gözet, 2018. Food waste matters-A systematic review of household food waste practices and their policy implications. Journal of Cleaner Production, 182, 978-991.

Singh, D., and P. Jain, 2016. IoT Based Smart Refrigerator System”. International Journal of Advanced Research in Electronics and Communication Engineering, 5(7), 2080-2084

Sonestedt, E., N. Øverby, D. Laaksonen, and B.E. Birgisdottir, 2012. Does high sugar consumption exacerbate cardiometabolic risk factors and increase the risk of type 2 diabetes and cardiovascular disease? Food \& nutrition research, 56(1), 19104

Spada, A., A. Conte and M.A. Del Nobile, 2018. The influence of shelf life on food waste: A model-based approach by empirical market evidence. Journal of Cleaner Production, 172, 3410-3414.

Stancu, V., P. Haugaard, and L. Lähteenmäki, 2016. Determinants of consumer food waste behaviour: Two routes to food waste. Appetite, 96, 7-17.

Stenmarck, A., C. Jensen, T. Quested, and G. Moates, 2016. Estimates of European food waste levels, March 2016, FUSIONS project, ISBN: 978-91-88319-01-2

Stuart, T., 2009. Waste: uncovering the global food scandal. Penguin Books. London.

Spada, A., A. Conte, and M.A. Del Nobile, 2018. The influence of shelf life on food waste: A model-based approach by empirical market evidence. Journal of Cleaner Production, 172, 3410-3414

Te Morenga, L., S. Mallard, and J. Mann, 2013. Dietary sugars and body weight: systematic review and meta-analyses of randomised controlled trials and cohort studies. Bmj, 346, e 7492.

Te Morenga, L.A., A.J. Howatson, R.M. Jones and J. Mann, 2014. Dietary sugars and cardiometabolic risk: systematic review and meta-analyses of randomized controlled trials of the effects on blood pressure and lipids-. The American journal of clinical nutrition, 100(1), 65-79.

Tessier, F.J., 2012. Effect of cooking on vitamins. CORRESPONDANCES EN METABOLISMES HORMONES DIABETES ET NUTRITION, 16(5-6), 150-153.

Trystram, G., 2010. The nutritional properties of frozen potato products. Cahiers de Nutrition et de Diététique, 45(Hors serie 1).

Van Boxstael, S., F. Devlieghere, D. Berkvens, A. Vermeulen, and M. Uyttendaele, 2014. Understanding and attitude regarding the shelf life labels and dates on pre-packed food products by Belgian consumers. Food Control, 37, pp.85-92.

van Gunst, A., A.J. Roodenburg, and I.H Steenhuis, 2018. Reformulation as an Integrated Approach of Four Disciplines: A Qualitative Study with Food Companies. Foods, 7(4), 64: 116

van der Sman, R.G.M., and S. Renzetti, 2018. Understanding functionality of sucrose in biscuits for reformulation purposes. Critical reviews in food science and nutrition, 1-15. 
Vanderroost, M., P. Ragaert, F. Devlieghere, and B. De Meulenaer, 2014. Intelligent food packaging: The next generation. Trends in Food Science \& Technology, 39(1), 47-62.

Vanderroost, M., P. Ragaert, J. Verwaeren, B. De Meulenaer, B. De Baets, and F. Devlieghere, 2017. The digitization of a food package's life cycle: Existing and emerging computer systems in the logistics and post-logistics phase. Computers in Industry, 87, 15-30

Ventour L. 2008. The food we waste: food waste report v2, WRAP. Oxford UK

Vermeiren, L., F. Devlieghere, M. Van Beest, N. De Kruijf, and J. Debevere, J. 1999.

Developments in the active packaging of foods. Trends in food science \& technology, 10(3), $77-86$

Werner, B. G., J.L. Koontz, and J.M. Goddard, 2017. Hurdles to commercial translation of next generation active food packaging technologies. Current Opinion in Food Science, 16, 4048.

Wilson, N.L., B.J. Rickard, R. Saputo, and S.T. Ho, 2017. Food waste: The role of date labels, package size, and product category. Food quality and preference, 55, 35-44.

Wittkopf, J., N. Ge, R. Ionescu, W. Staehler, D. Pederson, and H. Holder, 2018. Chipless RFID with Fully Inkjet Printed Tags: A Practical Case Study for Low Cost Smart Packaging Applications. In 2018 IEEE 68th Electronic Components and Technology Conference (ECTC) (pp. 940-947). IEEE.

WRAP, W. 2009. Household food and drink waste in the UK. Report prepared by WRAP. Banbury, $U K$

Wyness, L. A., J.L. Butriss, and S.A. Stanner, 2012. Reducing the population's sodium intake: the UK Food Standards Agency's salt reduction programme. Public health nutrition, 15(2), 254261.

Yam, K. L. 2000. Intelligent packaging for the future smart kitchen. Packaging Technology and Science: An International Journal, 13(2), 83-85.

Yam, K. L., P.T. Takhistov, and J. Miltz, 2005. Intelligent packaging: concepts and applications. Journal of food science, 70(1), R1-R10.

Yang G, L. Xie, M. Mäntysalo, X. Zhou, Z. Pang, L. Da Xu, S. Kao-Walter, Q. Chen, and L.R. Zheng, 2014. A health-IoT platform based on the integration of intelligent packaging, unobtrusive bio-sensor, and intelligent medicine box. IEEE transactions on industrial informatics. 10(4), 2180-91.

Zhang, X., G. Sun, X. Xiao, Y. Liu, and X. Zheng, 2016. Application of microbial TTIs as smart label for food quality: response mechanism, application and research trends. Trends in Food Science \& Technology, 51, pp.12-23

Zimmerman, M 2015. Hacking into your home: TVs, refrigerators could be portal to most sensitive information. Available at: https://www.foxnews.com/tech/hacking-into-your-hometvs-refrigerators-could-be-portal-to-most-sensitive-info [Accessed 28 October 2018] 


\begin{tabular}{|c|c|c|c|}
\hline $\begin{array}{l}\text { Method of } \\
\text { preservation }\end{array}$ & Principle & Health concern & Sources \\
\hline Heating & $\begin{array}{l}\text { Destruction of } \\
\text { microorganisms by } \\
\text { application of a time- } \\
\text { temperature scale. }\end{array}$ & $\begin{array}{l}\text { Enzyme inhibition and destruction of the } \\
\text { most sensitive nutrients including water- } \\
\text { soluble vitamins C, B } 1 \text { and B9 and fat- } \\
\text { soluble vitamins A and E and } \\
\text { micronutrients. Depending on the time } \\
\text { and temperature used spores could } \\
\text { survive the heat treatment. }\end{array}$ & $\begin{array}{l}\text { Tessier (2012) } \\
\text { Sadecka et al. (2014) } \\
\text { Duchene and Gandemer } \\
(2017) \\
\text { Trystram (2010) }\end{array}$ \\
\hline Cold & $\begin{array}{l}\text { Slows down the } \\
\text { development of } \\
\text { bacterial flora and } \\
\text { enzymatic activities. } \\
\text { Destroy parasites. }\end{array}$ & $\begin{array}{l}\text { Microbiological health risk in the case of } \\
\text { non-compliance with the cold chain. } \\
\text { Formation of ice crystals can modify the } \\
\text { organoleptic properties of meat products } \\
\text { and causing a loss of water-soluble } \\
\text { nutrients during thawing or oxidation. } \\
\text { Causes losses in some nutrients (e.g. } \\
\text { proteins, vitamin C, carotenoids) and } \\
\text { anti-nutrients in vegetables. Shelf-life } \\
\text { cannot exceed } 1 \text { month in order to avoid } \\
\text { mineral loss and deterioration. }\end{array}$ & $\begin{array}{l}\text { Armouche (2010) } \\
\text { Acho et al. (2015) } \\
\text { Gac (1992). }\end{array}$ \\
\hline $\begin{array}{l}\text { Salt \& } \\
\text { Sugar }\end{array}$ & $\begin{array}{l}\text { Decreases the water } \\
\text { activity by adding } \\
\text { sugar and salt as } \\
\text { osmotic agents and } \\
\text { block the development } \\
\text { of pathogenic } \\
\text { microorganisms. }\end{array}$ & $\begin{array}{l}\text { Sugar increases the risk of cavities, } \\
\text { promotes weight gain and has been } \\
\text { implicated in the occurrence and/or } \\
\text { complications associated with type } 2 \\
\text { diabetes. } \\
\text { Salt can cause blood pressure issues, } \\
\text { strokes and cardiovascular disease. }\end{array}$ & $\begin{array}{l}\text { Hendriksen et al. (2017) } \\
\text { Asaria et al. (2007) } \\
\text { Maillot et al. (2017) } \\
\text { Te Morenga et al. (2013) } \\
\text { Te Morenga (2014) } \\
\text { Sonestedt et al. (2012) }\end{array}$ \\
\hline Additives & $\begin{array}{l}\text { Add preservatives } \\
\text { such as antioxidants, } \\
\text { acidifiers or packaging } \\
\text { gases. }\end{array}$ & $\begin{array}{l}\text { Over-consumption of certain additives } \\
\text { can lead to health complications of } \\
\text { varying importance. }\end{array}$ & $\begin{array}{l}\text { Brigand et al. (1998) } \\
\text { Krifa et al. (1990) }\end{array}$ \\
\hline $\begin{array}{l}\text { Smoking \& } \\
\text { Drying }\end{array}$ & $\begin{array}{l}\text { Reduce the water } \\
\text { available in the } \\
\text { product. } \\
\text { Formation of new } \\
\text { organic features. } \\
\text { Provide volatile } \\
\text { compounds including } \\
\text { some bacteriostatic } \\
\text { and antioxidant from } \\
\text { the smoke. }\end{array}$ & $\begin{array}{l}\text { The presence of carcinogenic and } \\
\text { hazardous molecules (e.g polycyclic } \\
\text { aromatic hydrocarbons or heterocyclic } \\
\text { aromatic amines) from the particulate } \\
\text { phase of smoke. } \\
\text { Loss of water-soluble nutrient and } \\
\text { destruction of thermosensitive nutrients. }\end{array}$ & $\begin{array}{l}\text { Knockaert (2002) } \\
\text { Gibis (2016) } \\
\text { Armouche (2014) } \\
\text { Hou et al. (2018) }\end{array}$ \\
\hline
\end{tabular}


Table 2. Examples of smart devices used in intelligent packaging and their principle of operation (Adapted from: Fang et al. 2017; Manning, 2017)

\begin{tabular}{|c|c|c|c|}
\hline Smart devices & Principle/reagents & $\begin{array}{l}\text { Information } \\
\text { given }\end{array}$ & Application \\
\hline Barcodes & $\begin{array}{l}\text { Symbology e.g. } \\
\text { through } 1 \mathrm{D}, 2 \mathrm{D} \text { and } \\
\text { QR barcodes }\end{array}$ & $\begin{array}{l}\text { Product and } \\
\text { manufacturer } \\
\text { information } \\
\text { including price, } \\
\text { date packed }\end{array}$ & $\begin{array}{l}\text { Product identification, } \\
\text { facilitating inventory control, } \\
\text { stock allocation, stock } \\
\text { reordering, and checkout. } \\
\text { Theft protection and anti- } \\
\text { counterfeiting }\end{array}$ \\
\hline $\begin{array}{l}\text { Radio frequency } \\
\text { identification(RFID) } \\
\text { tags }\end{array}$ & Radio waves & $\begin{array}{l}\text { Product and } \\
\text { manufacturer } \\
\text { information e.g. } \\
\text { shelf-life }\end{array}$ & $\begin{array}{l}\text { Product identification, supply } \\
\text { chain management, asset } \\
\text { tracking, security control. } \\
\text { Information sharing, } \\
\text { electronic payment, } \\
\text { inventory management, } \\
\text { promotions management }\end{array}$ \\
\hline $\begin{array}{l}\text { Time-temperature } \\
\text { indicators }\end{array}$ & $\begin{array}{l}\text { Mechanical, chemical, } \\
\text { enzymatic, } \\
\text { microbiological e.g. } \\
\text { thermochromatic inks }\end{array}$ & $\begin{array}{l}\text { Storage } \\
\text { conditions }\end{array}$ & $\begin{array}{l}\text { Foods stored under chilled } \\
\text { and frozen conditions }\end{array}$ \\
\hline Gas indicators & $\begin{array}{l}\text { Redox dyes, pH dyes, } \\
\text { enzymes }\end{array}$ & $\begin{array}{l}\text { Storage } \\
\text { conditions, } \\
\text { package leak }\end{array}$ & $\begin{array}{l}\text { Foods stored in packages } \\
\text { with required gas } \\
\text { composition }\end{array}$ \\
\hline $\begin{array}{l}\text { Freshness indicators } \\
\text { (e.g. microbial } \\
\text { growth) }\end{array}$ & $\begin{array}{l}\text { pH dyes; Dyes } \\
\text { reacting with (non-) } \\
\text { volatile metabolites }\end{array}$ & $\begin{array}{l}\text { Microbial } \\
\text { quality of food } \\
\text { (i.e. spoilage) }\end{array}$ & $\begin{array}{l}\text { Perishable foods such as } \\
\text { meat, fish and poultry }\end{array}$ \\
\hline $\begin{array}{l}\text { Pathogen indicators/ } \\
\text { biosensors }\end{array}$ & $\begin{array}{l}\text { Various chemical and } \\
\text { immunochemical } \\
\text { methods reacting with } \\
\text { toxins }\end{array}$ & $\begin{array}{l}\text { Specific } \\
\text { pathogenic } \\
\text { bacteria such as } \\
\text { E. coli } \mathrm{O} 157\end{array}$ & $\begin{array}{l}\text { Perishable foods such as } \\
\text { meat, fish and poultry, } \\
\text { freshness indicators }\end{array}$ \\
\hline General biosensors & $\begin{array}{l}\text { Identification of } \\
\text { analytes in food, } \\
\text { allergenic proteins }\end{array}$ & $\begin{array}{l}\text { Presence of } \\
\text { chemicals or } \\
\text { allergens }\end{array}$ & All foods \\
\hline $\begin{array}{l}\text { Electronic Article } \\
\text { Surveillance }\end{array}$ & $\begin{array}{l}\text { holograms, micro- } \\
\text { tags, tear labels and } \\
\text { tapes }\end{array}$ & $\begin{array}{l}\text { Identification } \\
\text { mark, location } \\
\text { information }\end{array}$ & $\begin{array}{l}\text { Anti-counterfeiting, anti- } \\
\text { tamper and anti-theft devices }\end{array}$ \\
\hline
\end{tabular}


Table 3. Timeline for the development of intelligent fridges (Adapted from Osisanwo et al. 2015; Prapulla et al. 2015; Cotrim, 2016; Bonaccorsi et al. 2017)

\begin{tabular}{|c|c|}
\hline Year & \\
\hline 1998 & $\begin{array}{l}\text { First refrigerator connected to the Internet - recorded and transmitted every time } \\
\text { the fridge door was opened. }\end{array}$ \\
\hline 1999 & $\begin{array}{l}\text { Electrolux Screenfridge designed to allow users to order groceries over the } \\
\text { Internet. }\end{array}$ \\
\hline 2000 & $\begin{array}{l}\text { Whirlpool Cisco allowed users to watch a celebrity chef on the web-pad and had } \\
\text { an integrated web browser to search for recipes that match food items in the } \\
\text { household. LG launches Internet Digital DIOS fridge that can identify products } \\
\text { stored inside the fridge and track stock. }\end{array}$ \\
\hline 2002 & $\begin{array}{l}\text { Whirlpool's fridge was developed into a multimedia communications centre to } \\
\text { interact with the Internet, receive emails, listen to ratio, watch TV, videos and } \\
\text { DVDs and talk on the phone. }\end{array}$ \\
\hline 2003 & $\begin{array}{l}\text { LG Digital Multimedia Side-By-Side Fridge Freezer with LCD Display and built } \\
\text { in MP3 player that interacted with internet for re-stocking, media updates, email, } \\
\text { video mail, built in camera and microphone. }\end{array}$ \\
\hline 2006 & $\begin{array}{l}\text { Electrolux Screenfridge updated with } 15 \text { " touch screen and pop-up keyboard that } \\
\text { can connect to internet and TV wirelessly, email, phone, radio, MP3 player, } \\
\text { calendar, video messaging. }\end{array}$ \\
\hline 2007 & $\begin{array}{l}\text { Whirlpool fridge developed further with satellite radio, web tablet, interactive } \\
\text { message board, calendar, digital picture frame, DVD/CD player. }\end{array}$ \\
\hline 2009 & Samsung fridge had a detachable LCD screen and message board \\
\hline 2010 & LG developed a fridge that was internet enabled. \\
\hline 2011 & $\begin{array}{l}\text { Samsung developed the Futuristic RF4289 with } 8 \text { " touch screen and internet } \\
\text { enabled. }\end{array}$ \\
\hline 2015 & $\begin{array}{l}\text { LG HomeChat appliances includes internal wide angle camera that takes a picture } \\
\text { of the contents of the fridge every time the door is opened or closed. Freshness } \\
\text { Tracker software can provide information on products that have passed their } \\
\text { expiration date. }\end{array}$ \\
\hline 2016 & $\begin{array}{l}\text { Samsung FamilyHub - launch date April } 2016 \text { Main features - input app and } \\
\text { touch screen interface, music streaming, television, shopping lists, display of } \\
\text { photos, writing notes, doodling, shared fridge calendar, three cameras in fridge } \\
\text { that take an image every time door closes, tracking of expiration dates. } \\
\text { Whirlpool CES } 2016 \text { - launch date May } 2016 \text { - WiFi connected and can be } \\
\text { controlled remotely using an app and can notify user if fridge loses power or } \\
\text { needs a filter. }\end{array}$ \\
\hline 2018 & $\begin{array}{l}\text { Samsung FamilyHub and LG Smart ThinQ. Main features are: a food stock } \\
\text { management tool: a WiFi LCD tablet based screen for information, a camera or } \\
\text { glass door to see contents. Shopping help: videos or photos from the inside of } \\
\text { the fridge or on other models the ability to purchase directly from the fridge. } \\
\text { Shelf-life management by interacting with smart packaging, and warnings on } \\
\text { the need to use certain products. Planning cooking: recipes proposed with one } \\
\text { or more selected products, and the ability to create a weekly meal plan. The } \\
\text { difficulty is that food management systems require manual input from users } \\
\text { Android and iOS applications makes the inventory and product expiry data } \\
\text { remotely accessible, and a ZigBee radio device enables communication with } \\
\text { third-party smart plugs for energy monitoring. }\end{array}$ \\
\hline
\end{tabular}




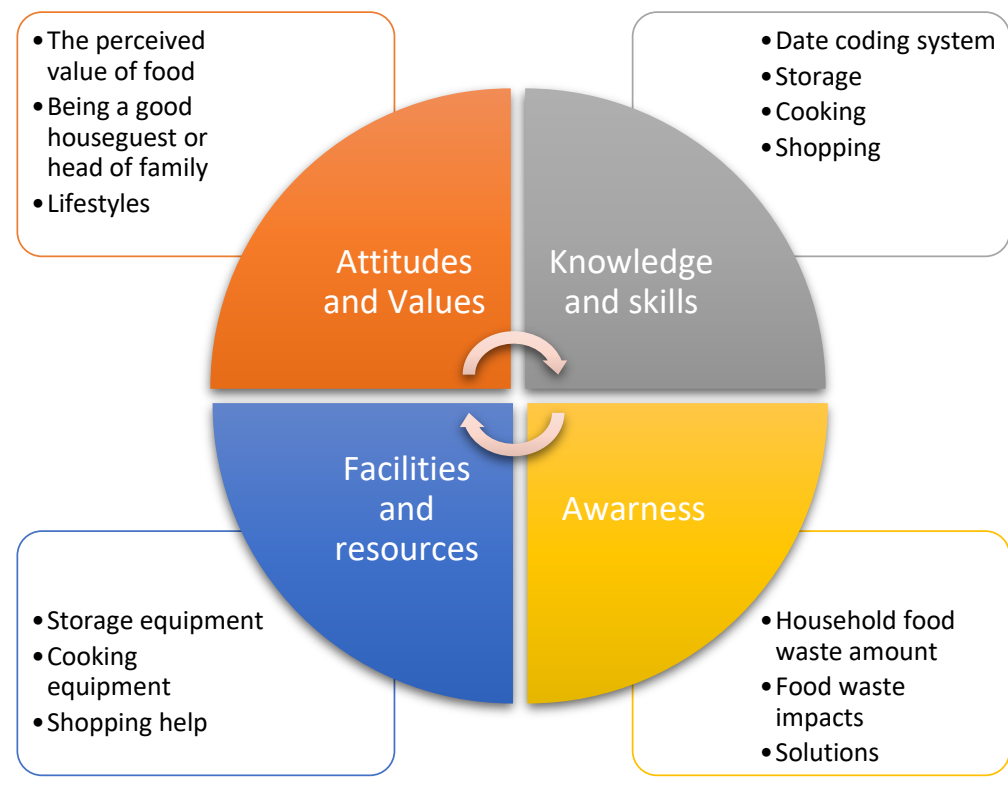

FIGURE 1 : Main causes of household food waste. (Adapted from Quested et al. 2011; Osborn, 2016; 
eg plain biscuits, flour, sliced bread, ambient stable tinned

food, frozen food, bottled water, UHT milk, dried pasta eg pre-cut fresh fruit \& vegetables, some chilled ready meals, cooked sliced meats, sandwiches, cold smoked salmon

Q2: Is it likely that microbiological changes could result in the food becoming an immediate danger to human health (for example, due to growth and/or toxin production by microorganisms to unsafe levels) after a short period of time? meals, cooked sliced meats, sandwiches, cold smoked salmon.

Q3: Is the food ready to eat (i.e. is it intended by the producer or the manufacturer for direct human consumption without the need for cooking or other processing effective to reduce to an acceptable level or eliminate microorganisms of concern)?

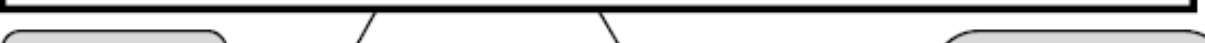

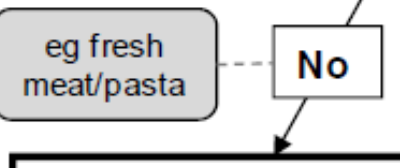

Q4: Could any microbiological hazard remain after the intended cooking or other processing?

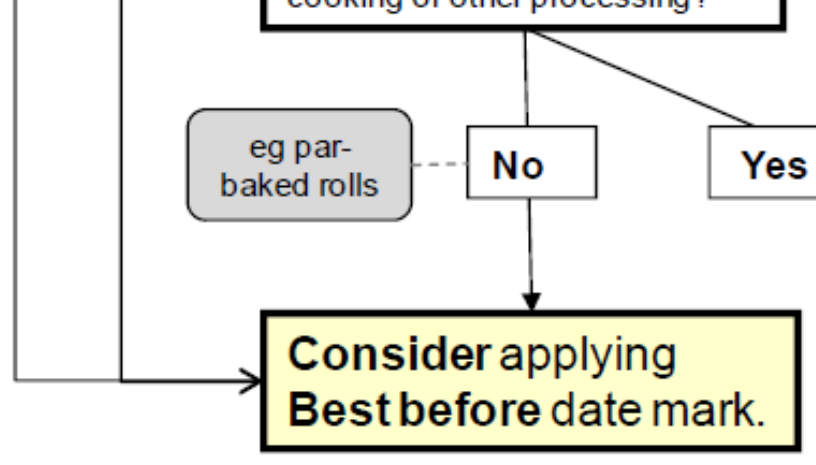

eg some cooked sliced meats, some sandwiches, cold smoked salmon,

eg some chilled ready meals, fresh meats, fresh pasta

\section{Consider applying Use} by date mark 


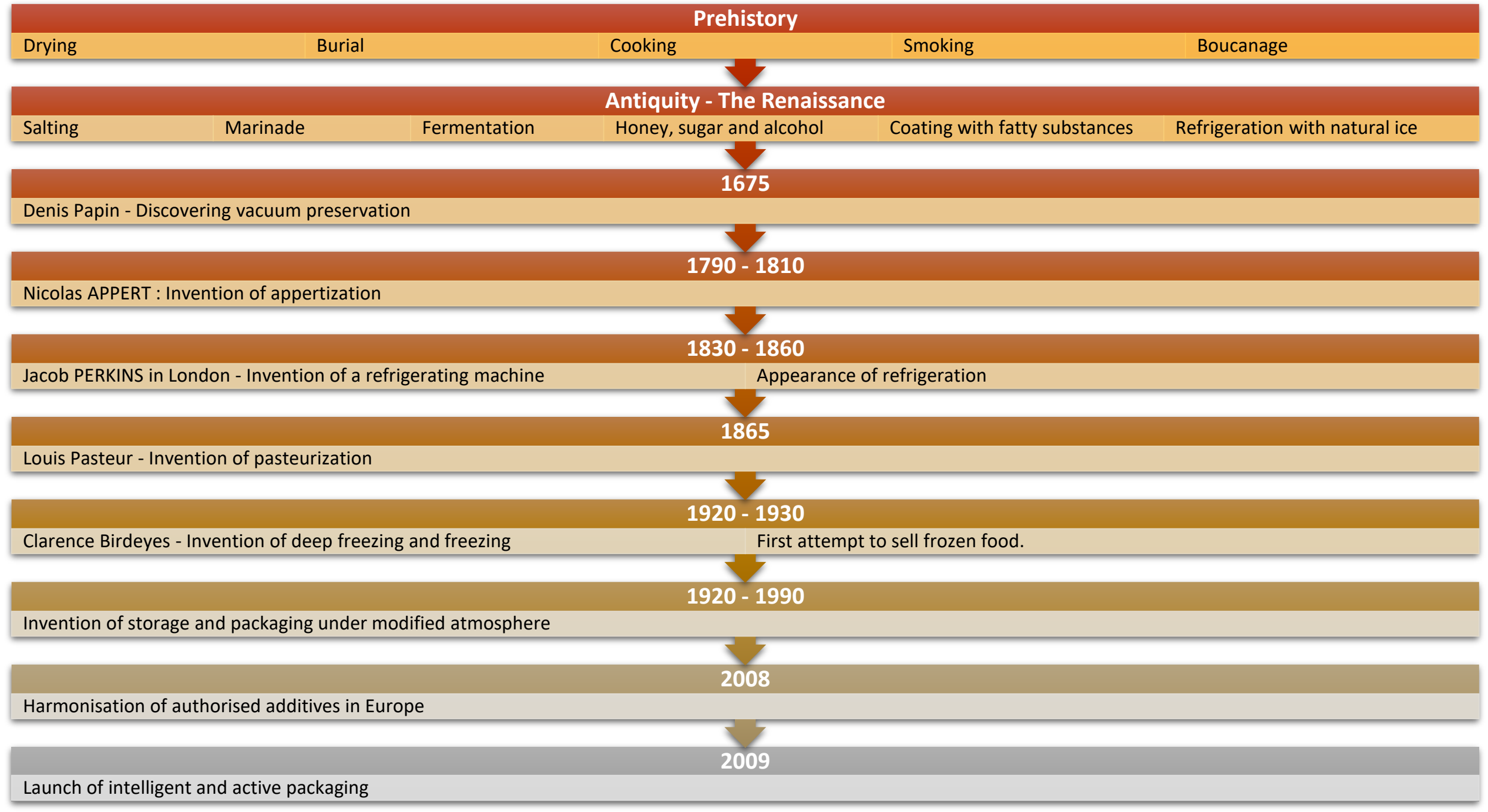


881 Figure 3: Timeline of Shelf-life extension technologies (Adapted from: Béné, 2009, 882 Ministère de l'agriculture et de l'alimentation, 2014; Hayat, 2016, Fournier, nd)

883

884

885 